\title{
EFFECT OF ZN CONCENTRATION IONS ON CORROSION BEHAVIOR OF ZINC PHOSPHATE CONVERSION COATING ON AL-MG-ZN ALLOY
}

\author{
A. A. Omar ${ }^{1}$, M. M. Sadawy ${ }^{1}$, R. M. Khalil ${ }^{1,2}$ \\ ${ }^{1}$ Mining and Pet. Dept., Faculty of Eng., Al-Azhar University, Nasr City Cairo, Egypt \\ ${ }^{2}$ Petroleum pipelines Co. Egypt
}

\begin{abstract}
The effect of $\mathrm{Zn}^{2+}$ concentrations on the formation of zinc phosphate conversion coatings (ZPCCs) on Al-Mg-Zn alloy was investigated. The morphology of the coatings was studied by scanning electron microscopy (SEM) and X-ray diffraction (XRD). The corrosion resistances of the coated and uncoated samples were evaluated by open circuit potential and potentiodynamic polarization techniques. The results revealed that the conversion coating consists of hopeite as a single phase. Furthermore, the results indicated that the corrosion resistance of the coated Al-Mg$\mathrm{Zn}$ samples was found to increase with increasing $\mathrm{Zn}^{2+}$ concentration.
\end{abstract}

\section{Keywords: Zinc phosphate coating; Aluminum alloys; Corrosion resistance}

\section{INTRODUCTION}

Aluminum alloys have high strength-to-weight ratio that makes them attractive for applications in the aerospace industry [1-3]. Aluminum is alloyed to increase the strength by forming intermetallic compounds (IMCs); however, IMCs that are more cathodic than aluminum can also increase the susceptibility of the alloys to corrosion. The most frequently used classes of aluminum alloys in the aerospace industry are the 2000 and 7000 series, which have copper and zinc, respectively, as the predominant alloying elements [4]. Two common alloys are 2024 with nominal alloying additions (all in wt\%) of $\mathrm{Cu}-4.4 \%, \mathrm{Mg}-1.5 \%$, and $\mathrm{Mn}-0.6 \%$ and 7075 with nominal alloying additions of $\mathrm{Zn}-5.6 \%, \mathrm{Mg}-2.5 \%, \mathrm{Cu}-1.6 \%$, and $\mathrm{Cr}-0.23 \%$ [4]. Both alloys contain magnesium as a secondary alloying addition.

Aluminum is highly reactive and forms a self-healing, passive oxide layer that can protect the underlying alloy from atmospheric corrosion [1,3,5]. For magnesium-containing alloys such as 7075 , magnesium diffuses to the surface during heat treatment, thereby producing a magnesiumrich surface oxide [4]. It was suggested that magnesium diffuses to the surface through the $\mathrm{Al}_{2} \mathrm{O}_{3}$ grain boundaries to form $\mathrm{MgO}$. Further, magnesium can even reduce the native alumina to metallic aluminum so that the aluminum-rich oxide layer may also contain some metallic aluminum [4].

In order to reduce the tendency towards corrosion and improve the adhesion with the paint, the aluminium alloy surface is typically modified by a chromate-based chemical conversion pretreatment. Despite the undeniable qualities and advantages of this chromate treatment, such technology should be soon withdrawn from any industrial process since hexavalent chromium has been recognized to be highly toxic and carcinogenic [6]. Currently, much effort was made to develop more freindly alternatives. Among the various reported 
alternatives, such as treatments with phosphate conversion coating (PCC) [7,8,]. PCC treatment was believed as one of the most promising systems, and many researchers according to Table 1 have reported many treating solutions which could effectively inhibit the corrosion of aluminum alloys.

Table 1. Chemical compositions of some zinc phosphate conversion coatings baths [9]

\begin{tabular}{|c|c|c|c|c|}
\hline Bath No. & Unit & $\mathrm{H}_{3} \mathrm{PO}_{4}$ & $\mathrm{Zn}\left(\mathrm{NO}_{3}\right)_{2}$ & $\mathrm{ZnO}$ \\
\hline 1 & $\mathrm{~g} / \mathrm{L}$ & 12.43 & 5.0 & \\
\hline 2 & $\mathrm{~g} / \mathrm{L}$ & 11.3 & 12.5 & 2.2 \\
\hline 3 & $\mathrm{~g} / \mathrm{L}$ & $7.0-7.5$ & & 2.36 \\
\hline 4 & $\mathrm{~g} / \mathrm{L}$ & 17.5 & & 3.2 \\
\hline 5 & $\mathrm{~g} / \mathrm{L}$ & 16.8 & & 3.2 \\
\hline 6 & $\mathrm{~g} / \mathrm{L}$ & 27.2 & & 6.8 \\
\hline
\end{tabular}

According to Table 1 , a wide range of $\mathrm{Zn}^{2+}$ concentration has been used to form ZPCC solution for $\mathrm{Al}$ alloys. The studies in Table 1 have focused on fundamental aspects of ZPCC process, characterization of coatings and effect of some additional agents to improve coatings quality. However, the effect of $\mathrm{Zn}^{2+}$ concentration on the formation of $\mathrm{ZPCCs}$ on Al-Zn-Mg alloy has not been reported. Therefore, the aim of this study is to investigate the effects of $\mathrm{Zn}^{2+}$ concentration on the formation and characteristics of the ZPCC. Furthermore, the corrosion resistance of the ZPCCs was investigated.

\section{EXPERIMENTAL WORK}

\subsection{Substrate and coating}

The present study was carried out using AA 7075-T6 rods, which was obtained from 63Egyptian armed factory and has the nominal composition as shown in Table.

Table 2. Chemical composition of AA7075 Al alloy in (wt. \%).

\begin{tabular}{|cc|c|c|c|c|c|}
\hline Elements & $\mathrm{Zn}$ & $\mathrm{Mg}$ & $\mathrm{Cu}$ & $\mathrm{Cr}$ & $\mathrm{Fe}$ & $\mathrm{Al}$ \\
\hline Wt.\% & 5.3 & 2.45 & 1.67 & 0.21 & 0.24 & Bal. \\
\hline
\end{tabular}

The rods were cut into samples with $11 \mathrm{~mm}$ diameter and $20 \mathrm{~mm}$ length. The surfaces were chemically pickled with $5 \% \mathrm{KOH}$ for $3 \mathrm{~min}$, and then rinsed 3 times with deionized water. After rinsing, the samples were immersed for $20 \mathrm{~min}$ in a phosphating bath of $20 \mathrm{ml} / \mathrm{L}(85 \%) \mathrm{H}_{3} \mathrm{PO}_{4}$, $4.0 \mathrm{~g} / \mathrm{L} \mathrm{NaNO}{ }_{3}$ and different amount of $\mathrm{ZnO}(3,6,912 \mathrm{~g} / \mathrm{L})$ at temperature of $80{ }^{\circ} \mathrm{C}$. After the phosphate treatment, the samples were rinsed with deionized water and dried in ambient air.

\subsection{Electrochemical measurements}

The corrosion analysis was performed by A Potentiostat/Galvanostat (EG\&G model 273) and a personal computer were used. M352 corrosion software from EG\&G Princeton Applied Research was used for the potentiodynamic polarization, and the current/time transient measurements. A three-electrode cell composed of a specimen as a working electrode, Pt counter electrode, and $\mathrm{Ag} / \mathrm{AgCl}$ reference electrode were used for the tests.

Polarization tests were carried out at a scan rate of $0.5 \mathrm{mv} / \mathrm{s}$ at room temperature. Specimens with exposed surface area of $2 \mathrm{~cm}^{2}$ were used as a working electrode. The potentiodynamic curves were recorded by changing the electrode potential, including compensation for the ohmic drop 
potential of the solution, automatically from $-0.250 \mathrm{~V} \mathrm{E}_{\text {cor }}$ to the required anodic potential at a potential scan rate of $0.5 \mathrm{mvs}^{-1}$. For each run, a freshly prepared solution as well as a cleaned set of electrodes was used. Each run was carried out in aerated stagnant solutions at room temperature. At least three separate experiments were carried out for each run to ensure reproducibility of results. The reproducibility of the polarization curves was good.

The PAR Calc Tafel Analysis routine statistically fits the experimental data to the Stern-Geary model for a corroding system. The routine automatically selects the data that lies within the Tafel region $( \pm 250 \mathrm{mV}$ with respect to the corrosion potential). It then calculates the corrosion current and the corrosion rate. The solutions were prepared using analytical reagent grade chemicals and distilled water. The volume of the test solution was $250 \mathrm{ml}$.

\subsection{Surface analysis}

Scanning electron microscope (SEM) associated with energy dispersion X-ray (EDX) spectrometry was used to observe the morphology of zinc phosphating coating. The structure of the phosphate layer was also determined using X-ray diffraction (XRD, Philips Analytical X-ray B.V. Machine).

\section{RESULTS AND DISCUSSIONS}

\subsection{Coatings formation and characterization}

Thermodynamic stability diagram showing $\left[\mathrm{Zn}^{2+}\right]$ for precipitation of hopeite $\left(\mathrm{Zn}_{3}\left(\mathrm{PO}_{4}\right)_{2} 4 \mathrm{H}_{2} \mathrm{O}\right)$ calculated using the HSC software package is shown in Fig. 1. It can be seen that the hopeite can be precipitated readily in the bath. The reactions which lead to formation of hopeite can be as follows [10-13]:

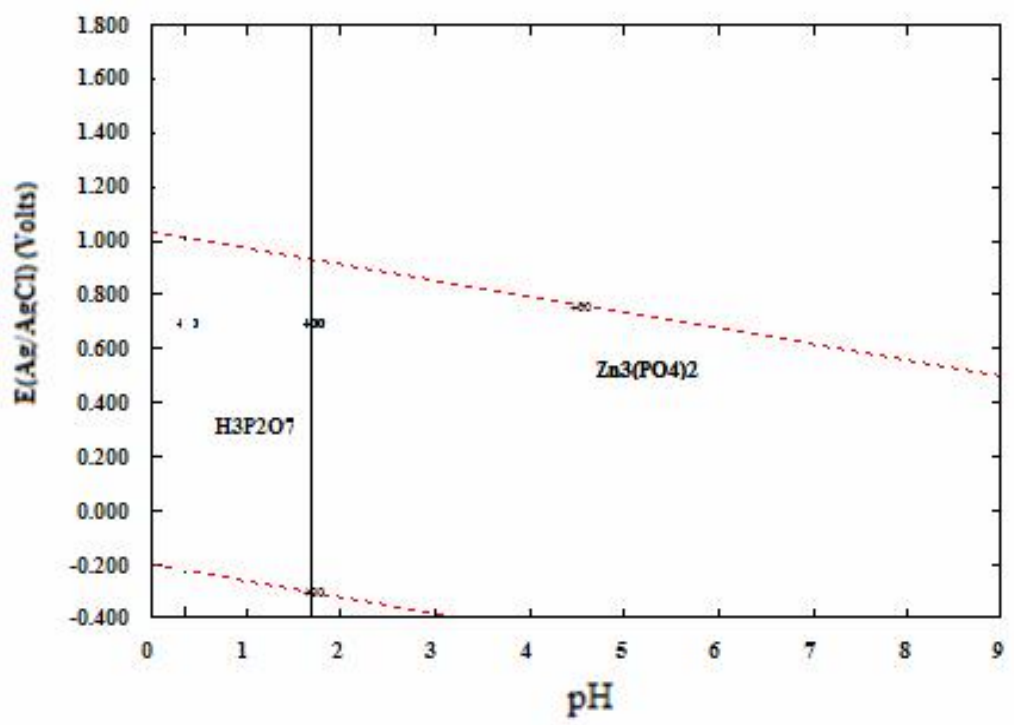

Fig. 1: Thermodynamic stability diagram showing $\left[\mathrm{Zn}^{2+}\right]$ for precipitation of hopeite $\left(\mathrm{Zn}_{3}\left(\mathrm{PO}_{4}\right)_{2}\right.$ calculated using the HSC software package

$\mathrm{ZnO}+2 \mathrm{H}_{3} \mathrm{PO}_{4}+\mathrm{H}_{2} \mathrm{O} \rightarrow \mathrm{Zn}\left(\mathrm{H}_{2} \mathrm{PO}_{4}\right)_{2} \cdot 2 \mathrm{H}_{2} \mathrm{O}$

The product $\mathrm{Zn}\left(\mathrm{H}_{2} \mathrm{PO}_{4}\right)_{2} .2 \mathrm{H}_{2} \mathrm{O}$ of reaction (1) is soluble and it dissolved in the solution to produce:

$\mathrm{Zn}\left(\mathrm{H}_{2} \mathrm{PO}_{4}\right)_{2} \cdot 2 \mathrm{H}_{2} \mathrm{O} \Leftrightarrow \mathrm{ZnPO}^{-4}+\mathrm{H}_{2} \mathrm{PO}^{-4}+2 \mathrm{H}^{+}+2 \mathrm{H}_{2} \mathrm{O}$

The complex ion $\mathrm{ZnPO}^{4-}$ has the ionization reaction as follow: 


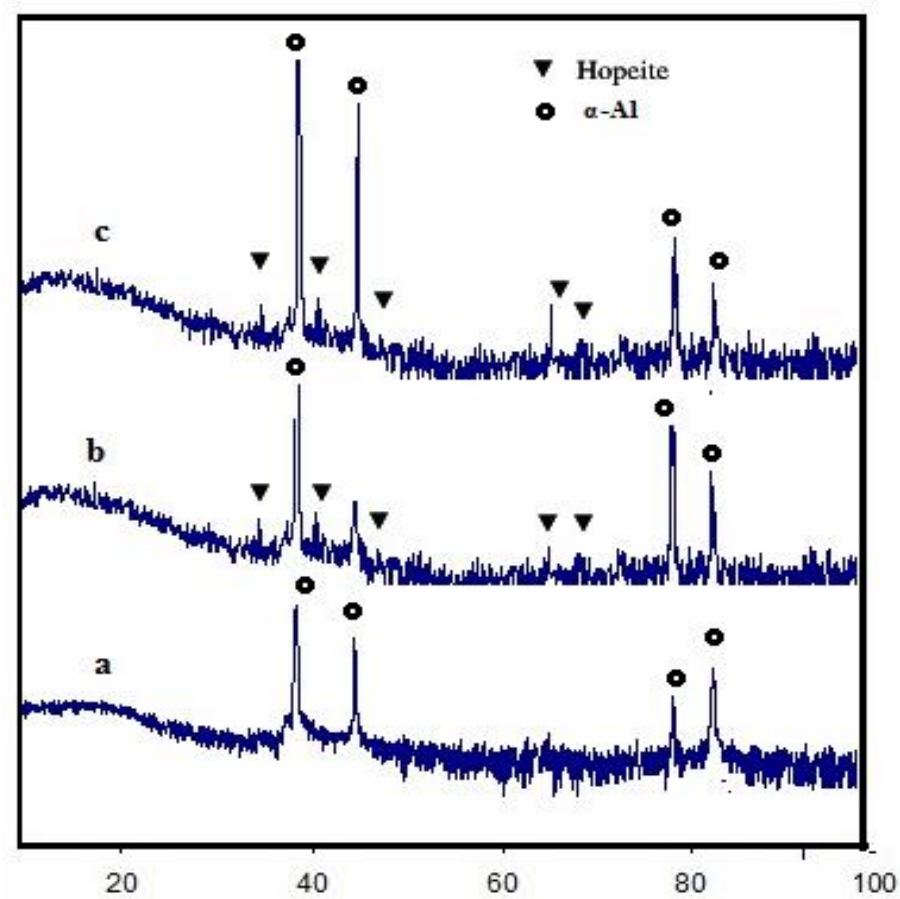

Fig. 2: The X-ray diffraction pattern of Al-Zn-Mg-Cu alloy before and after coating

$\mathrm{ZnPO}^{-4} \Leftrightarrow \mathrm{Zn}^{2+}+\mathrm{PO}_{4}{ }^{3-}$

In the phosphating bath, $\mathrm{Zn}\left(\mathrm{NO}_{3}\right)_{2}$ has two actions. First, it provides $\mathrm{Zn}^{2+}$ in the solution according to Eq. (4). Secondly it accelerates the phosphating process.

$\mathrm{Zn}\left(\mathrm{NO}_{3}\right)_{2} \rightarrow \mathrm{Zn}^{2+}+2 \mathrm{NO}_{3}$

The X-ray diffraction pattern of $\mathrm{Al}-\mathrm{Zn}-\mathrm{Mg}-\mathrm{Cu}$ alloy before and after coating is shown in Fig 2. It can be seen that the substrate (Fig. 2a) contains $\alpha$-Al solid grains. While Fig. 2b indicates that the coating formed on the substrate is a single phase coating, with the chemical formula of $\mathrm{Zn}\left(\mathrm{H}_{2} \mathrm{PO}_{4}\right)_{2} \cdot 2 \mathrm{H}_{2} \mathrm{O}$. 'Also it can be seen that with increasing $\mathrm{Zn}^{2+}$ concentration, the intensity of hopeite increases, while the $\alpha$-Al diffraction intensity decreases. The existence of $\mathrm{Zn}$ on the surface of the investigated alloy in absence of $\mathrm{Zn}$ is due to the dissolution of $\mathrm{Zn}$ from the alloy. The morphology of phosphating coating at different $\mathrm{Zn}$ concentration is shown in Fig 3. It can be seen that coatings have the same morphology. However, the uniformity and compactness of coating increase with increasing $\mathrm{Zn}$ concentration. Energy dispersive $\mathrm{X}$-ray analysis (EDX) technique was performed in order to get information about the composition of the surface of the investigated alloy. The results of EDX spectra are shown in Fig 4. The coatings were composed of zinc, phosphorus, oxygen, magnesium and aluminum. The percentage weight of various elements determined by EDX in marked points is shown in Tables 2. It can be seen that the content of zinc and phosphorus increase with increasing $\mathrm{Zn}$ concentration in the bath. This result is in agreement with X-ray analysis. 

ZN ALLOY
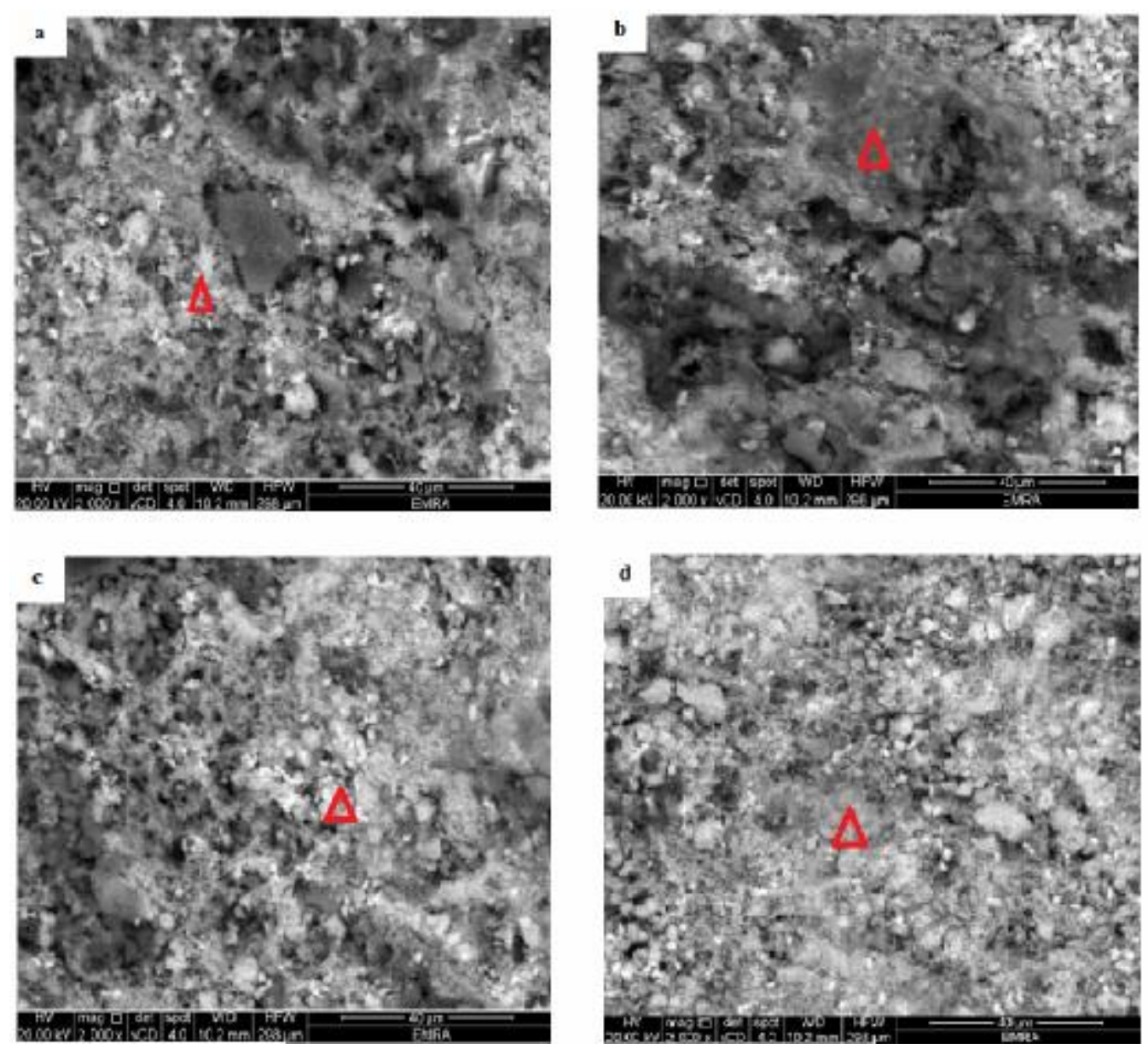

Fig. 3: Morphology of phosphating coating at different $\mathrm{Zn}$ ions concentration. a-0.0g/L , b-3.0g/L,c-6.0g/L and d- 9.0g/L ZnO

Table 3. Chemical composition of coating determined by EDX at different Zn concentration

\begin{tabular}{|c|c|c|c|c|c|}
\hline Sample & $\mathrm{Zn}$ & $\mathrm{Mg}$ & $\mathrm{O}$ & $\mathrm{P}$ & $\mathrm{Al}$ \\
\hline $0.0 \mathrm{~g} / \mathrm{L}$ & 3.54 & 1.24 & 27.45 & 5.78 & 61.99 \\
\hline $3.0 \mathrm{~g} / \mathrm{L}$ & 6.98 & 1.34 & 28.87 & 6.67 & 56.14 \\
\hline $6.0 \mathrm{~g} / \mathrm{L}$ & 8.46 & 1.76 & 28.98 & 6.89 & 53.91 \\
\hline $9.0 \mathrm{~g} / \mathrm{L}$ & 9.98 & 1.65 & 29.45 & 7.67 & 51.25 \\
\hline
\end{tabular}



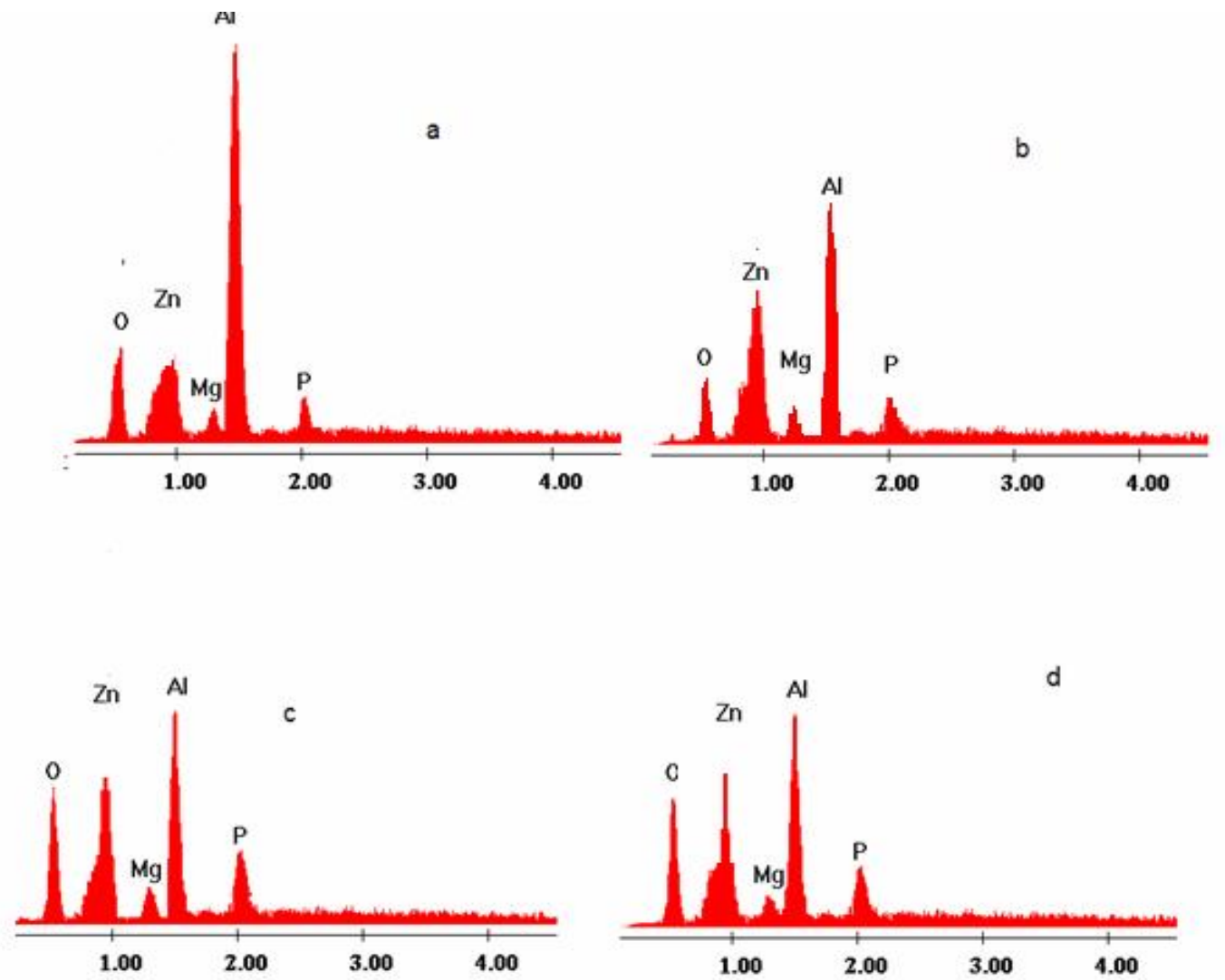

Fig. 4: EDX spectra of phosphating coating at different $\mathrm{Zn}$ ions concentration. a-0.0g/L , b-3.0g/L,c-6.0g/L and d- 9.0g/L ZnO

The effect of $\mathrm{Zn}$ concentration on coating weight is shown in Fig. 5. It is obvious that as $\mathrm{Zn}$ concentration increases, the weight of the coating increases. Furthermore, Fig 6 indicates the porosity as a function in $\mathrm{Zn}$ concentration. It can be seen that the porosity of the coating decreases with increase in $\mathrm{Zn}$ concentration. This behavior can be attributed to increasing the amount of metallic zinc formed on the surface especially in the first stage of coating. Jegannathan et. al [14] found that during the formation of zinc phosphate chemical conversion coating, in the initial periods metallic zinc coating is formed, followed by the codeposition of metallic zinc and nonmetallic zinc phosphate in subsequent stages. However, the ratio of metallic zinc to zinc phosphate is very high in the first stage of coating. 
EFFECT OF ZN CONCENTRATION IONS ON CORROSION BEHAVIOR OF ZINC PHOSPHATE CONVERSION COATING ON AL-MGZN ALLOY

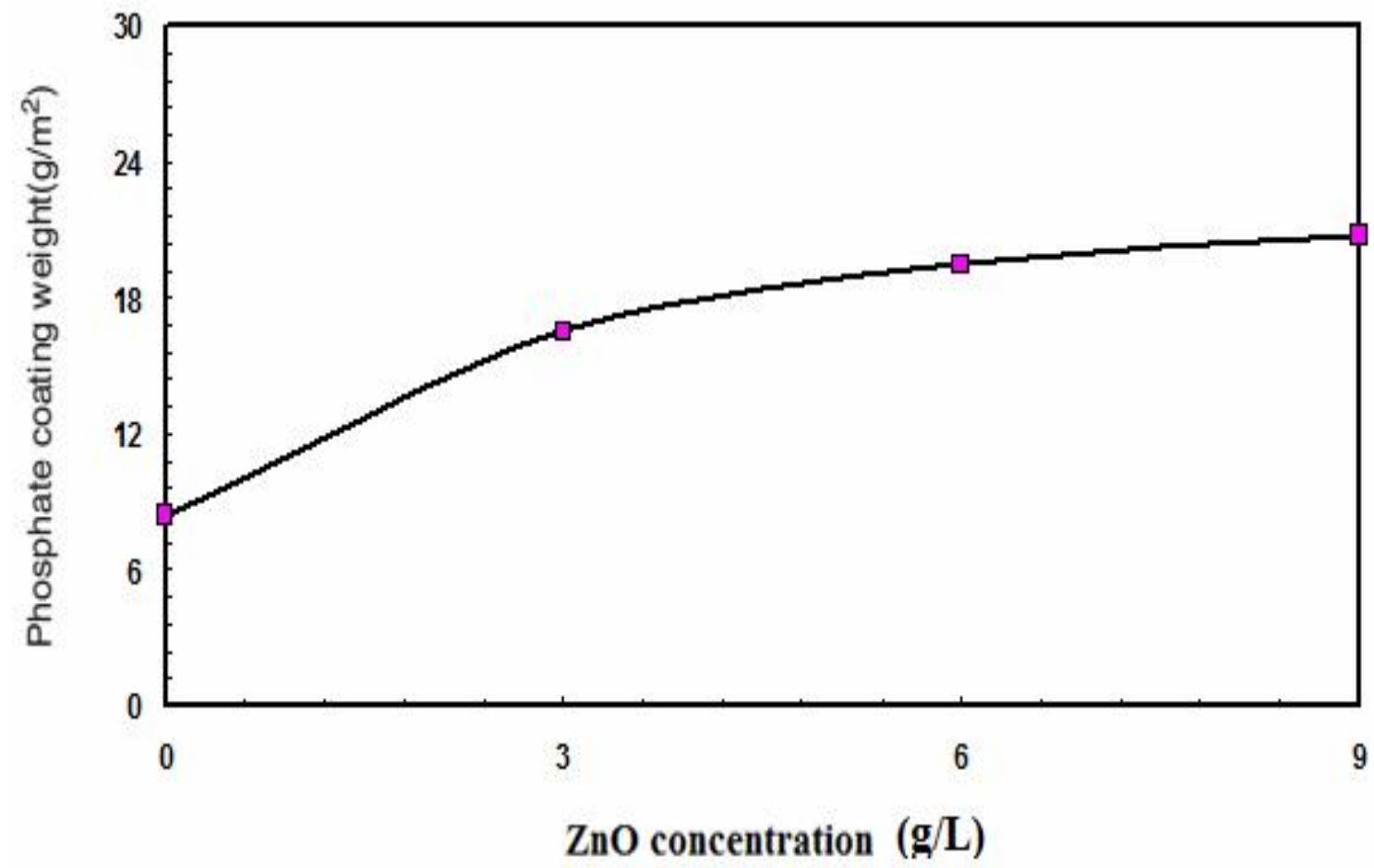

Fig. 5: The effect of $\mathrm{Zn}$ concentration on coating weight

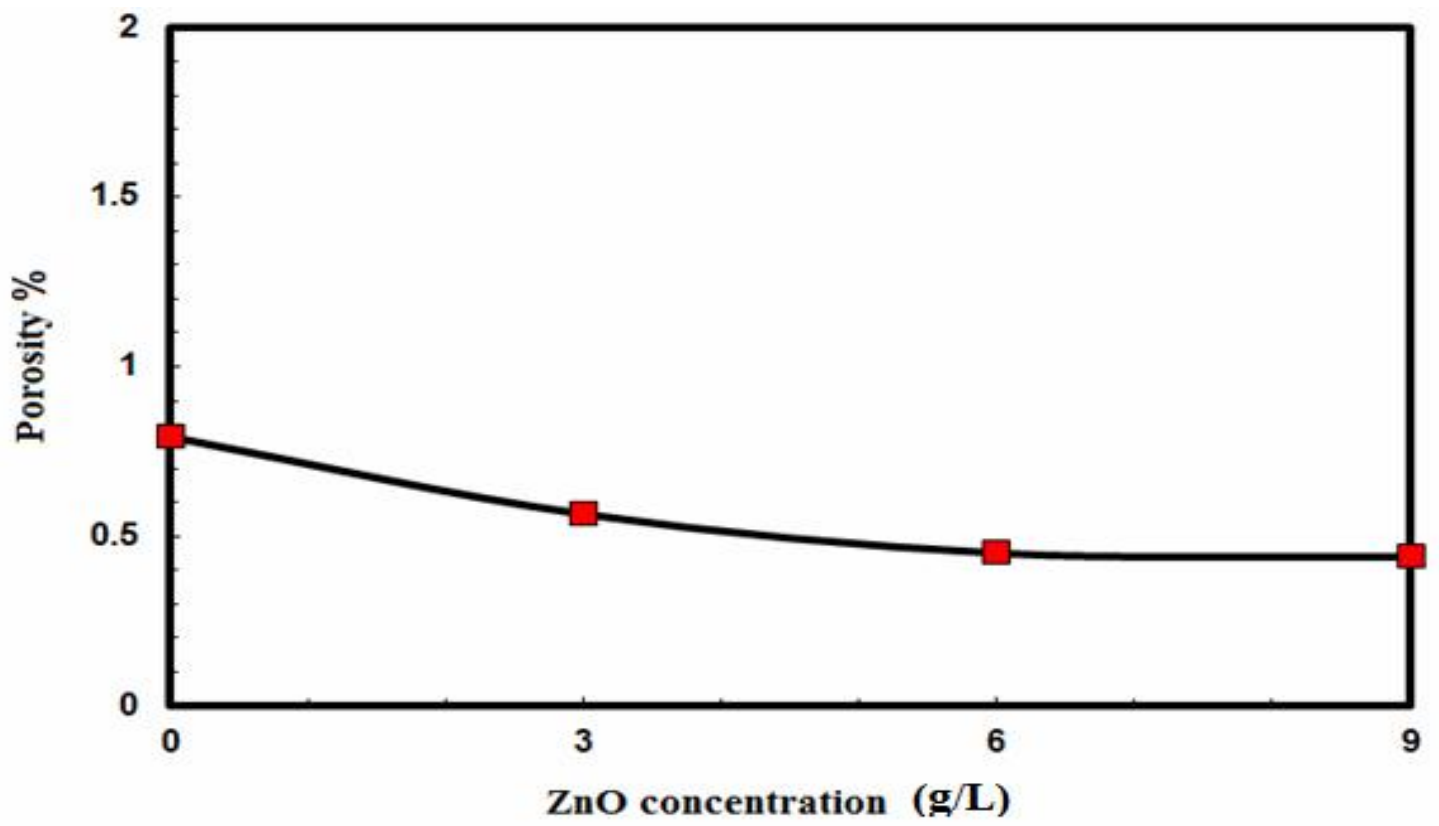

Fig. 6: The effect of $\mathrm{Zn}$ concentration on the porosity \% 


\subsection{Corrosion behavior}

\subsubsection{Open circuit potential}

The change in open circuit potential of phosphated and non-phosphated Al- $\mathrm{Zn}-\mathrm{Mg}$ alloy on monitored time in a $3.5 \mathrm{wt} \%$ solution are presented in Fig. 7 and 8 . In the case of nonphosphated $\mathrm{Al}-\mathrm{Zn}-\mathrm{Mg}$ alloy the OCP increased from its initial value of $-880 \mathrm{mV}$ to a stable value of $-900 \mathrm{mV}$ (Fig. 7 ). For the phosphated specimens with different zinc ions the initial value of OCP was more positive ( -460 to $-480 \mathrm{mV}$ ) but it increased with time. Its evolution depends on the amount of zinc concentration. They reach the limit of about -530 to $-510 \mathrm{mV}$ with increasing zinc ions from 0.0 to $9 \mathrm{~g} / \mathrm{l}$. This means that the porosity of the coating decreases with increase in $\mathrm{Zn}$ concentration. Therefore, the electrochemical reaction decreases [15].

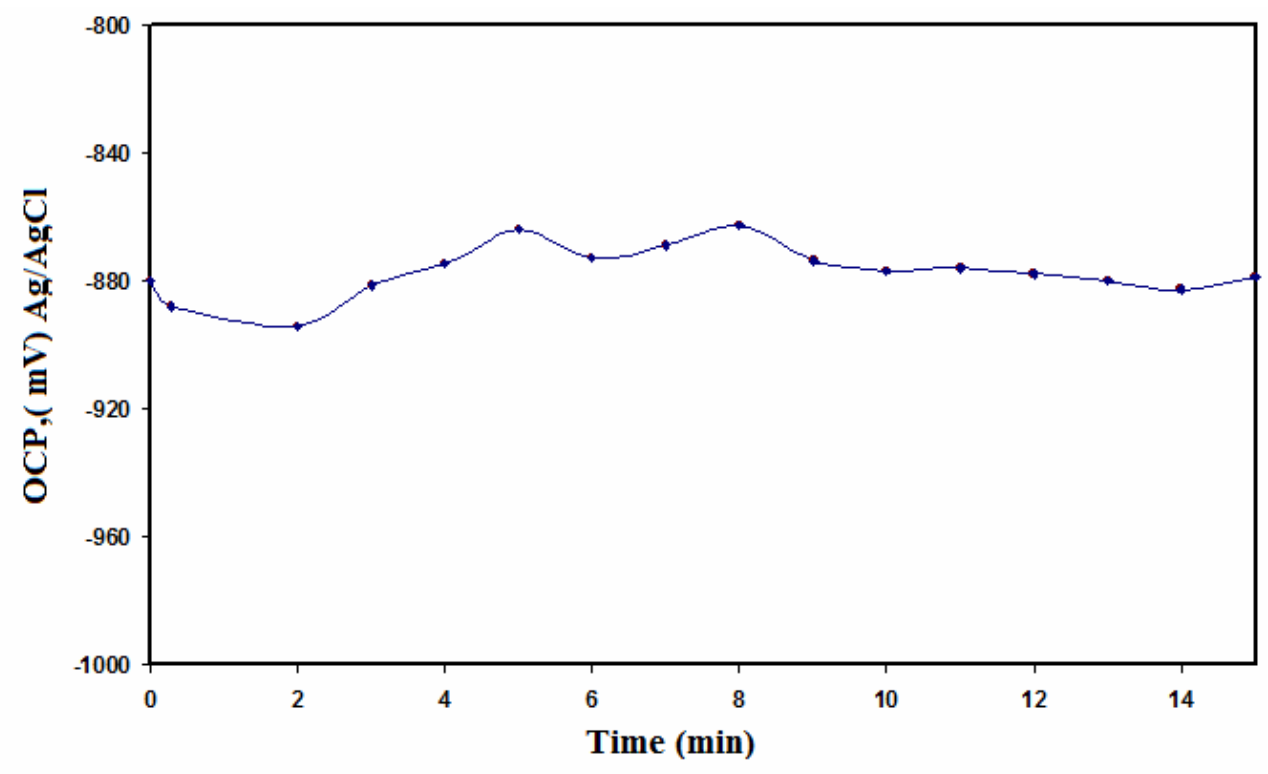

Fig. 7: OCP of uncoated Al-Mg-Zn alloy in $3.5 \mathrm{wt} \%$ solution

\subsubsection{Potentiodynamic polarization}

Potentiodynamic polarization of uncoated alloy in $3.5 \%$ wt. $\mathrm{NaCl}$ solution is shown in Fig. 9. It can be observed from potentiodynamic polarization curves that the cathodic and anodic curves show a regular pattern. The anodic current density continuously increased with increasing potential. This behavior shows that the alloy has active dissolution behavior in $3.5 \% \mathrm{wt} . \mathrm{NaCl}$ solution.

On the other hand, Fig. 10 shows the potentiodynamic polarization curves of phosphating coating with different $\mathrm{Zn}$ concentration on the surface of investigated alloy. The cathodic polarization curves show a regular pattern and the cathodic current densities decreases with increasing zinc concentration. The anodic curves show that with an increase in zinc concentration the corrosion potential $\left(\mathrm{E}_{\text {corr }}\right)$ shifts to more noble potential and the corrosion current density $\left(\mathrm{i}_{\text {corr }}\right)$ decreases. Electrochemical data obtained from the anodic polarization curves are presented in Table 3 . It can be seen that the corrosion rate decreases from 388 mpy to 5.74 mpy. This indicates that the formed layer has a good adhesion to the metal and provides an effective barrier to the metal dissolution. The anodic slope $\left(b_{a}\right)$, is similar for all samples, indicating that the coating acts as an anodic type inhibitor. 


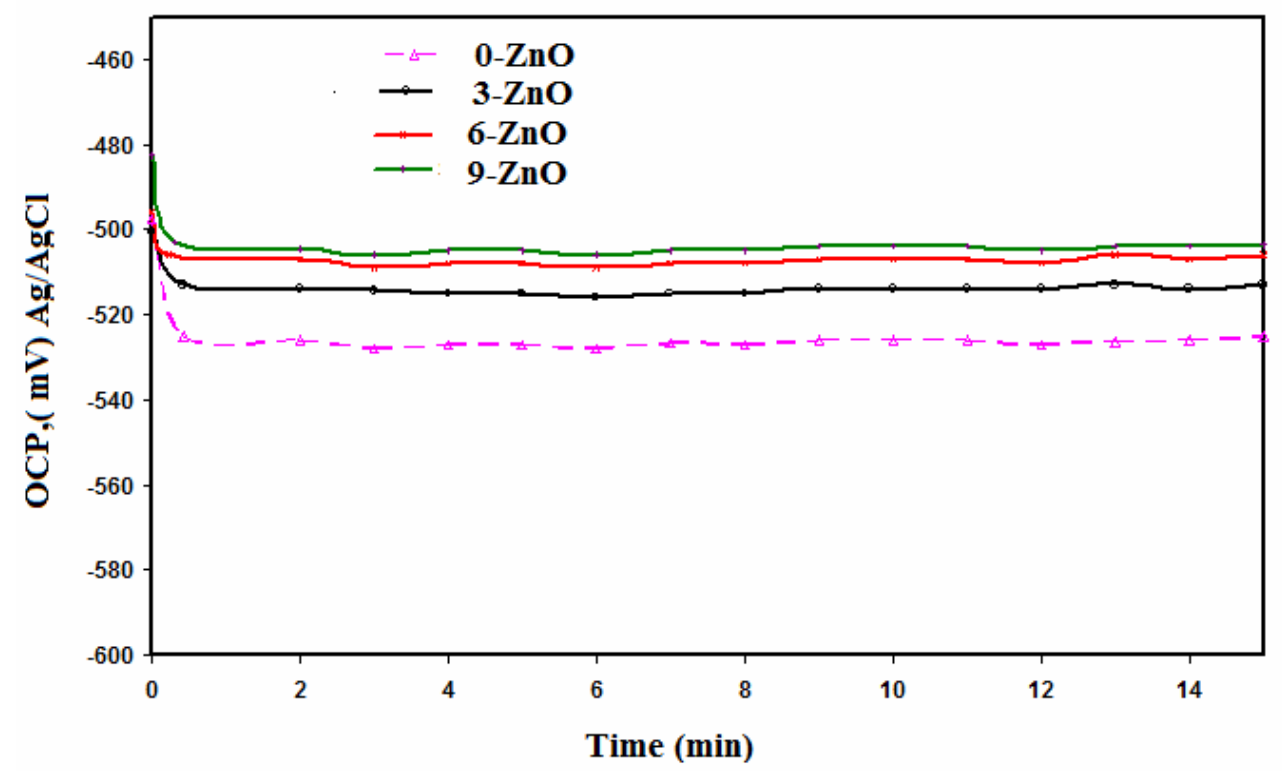

Fig. 8: OCP of phosphating coating with different $\mathrm{Zn}$ concentration alloy in $3.5 \mathrm{wt} \%$ solution

\subsubsection{Corrosion surface morphology}

The corrosion surface morphology of phosphated and non-phosphated $\mathrm{Al}-\mathrm{Zn}-\mathrm{Mg}$ alloy after 15 days constant immersion testing was observed using scanning electron microscopy (SEM) as shown in Figs 11 and 12 . It can be seen that of the non-phosphated Al-Zn-Mg alloy ( Fig. 11) suffers from and deep and large pits. While the coated samples exhibit a protective behavior on the surface (see Fig 12). This behavior is attributed to self-healing effect. Whereas the products of corrosion close some of available pore spaces on the surface and produce dense structure.

Table 4. Electrochemical parameters obtained from Tafel polarization measurements for coated and uncoated alloys in $3.5 \%$ wt. $\mathrm{NaCl}$ solution

\begin{tabular}{|c|c|c|c|c|c|}
\hline Sample & $\mathrm{E}_{\text {corr }}(\mathrm{mV})$ & $\mathrm{i}_{\text {corr }}\left(\mu \mathrm{A} / \mathrm{cm}^{2}\right)$ & $\mathrm{mpy}$ & $\beta_{\mathrm{c}}(\mathrm{mV} / \mathrm{dec})$ & $\beta_{\mathrm{a}}(\mathrm{mV} / \mathrm{dec})$ \\
\hline Uncoated & -733 & 905.8 & 388.54 & 302 & 229 \\
\hline $0.0 \mathrm{~g} / \mathrm{L}$ & -465 & 22.78 & 9.77 & 309 & 225 \\
\hline $3.0 \mathrm{~g} / \mathrm{L}$ & -439 & 16.9 & 7,25 & 383 & 228 \\
\hline $6.0 \mathrm{~g} / \mathrm{L}$ & -370 & 13.9 & 5.75 & 368 & 228 \\
\hline $9.0 \mathrm{~g} / \mathrm{L}$ & -356 & 13.4 & 5.74 & 358 & 227 \\
\hline
\end{tabular}


EFFECT OF ZN CONCENTRATION IONS ON CORROSION BEHAVIOR OF ZINC PHOSPHATE CONVERSION COATING ON AL-MGZN ALLOY

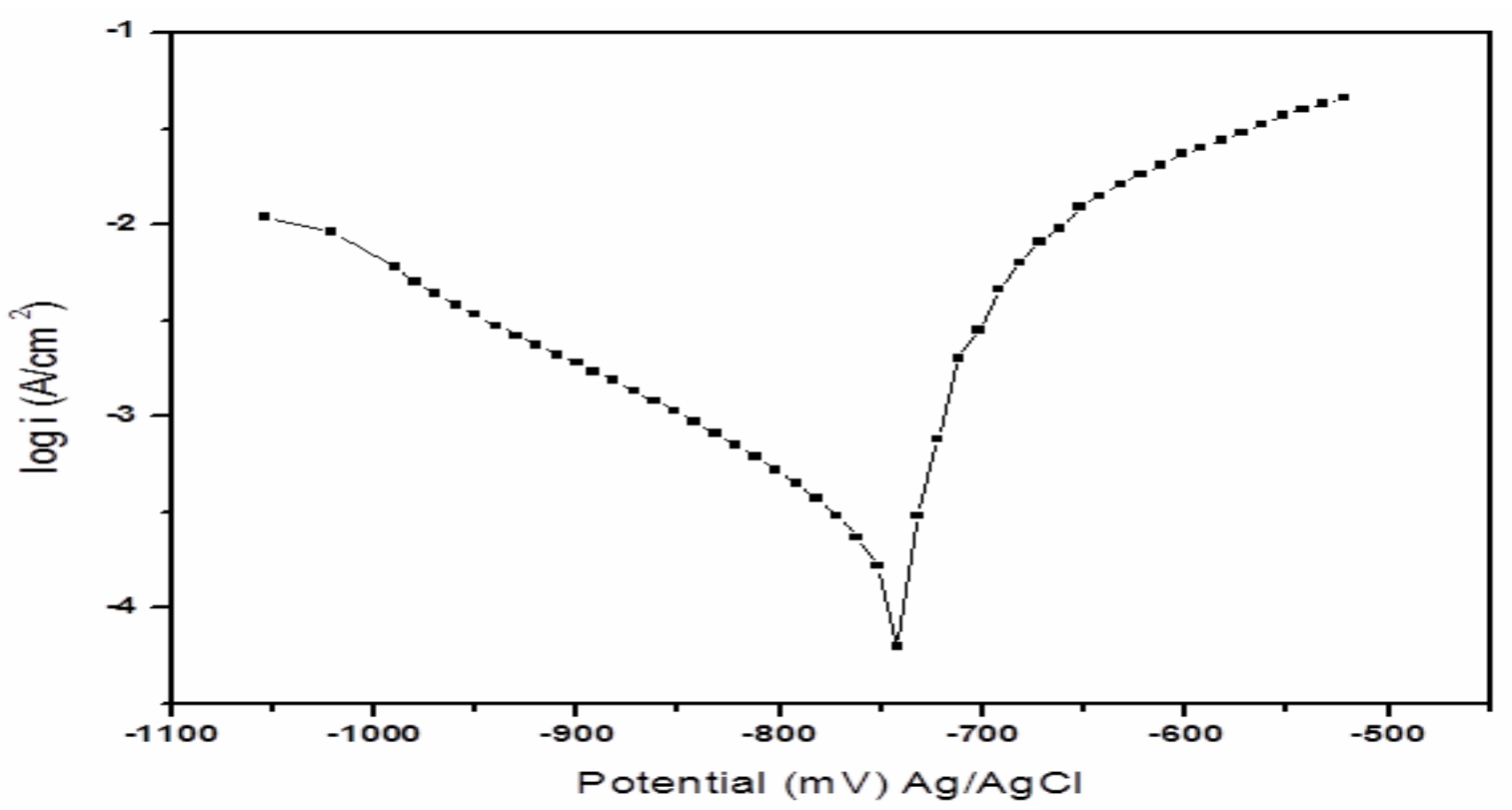

Fig. 9: potentiodynamic polarization of uncoated Al-Mg-Zn alloy in $3.5 \mathrm{wt} \%$ solution

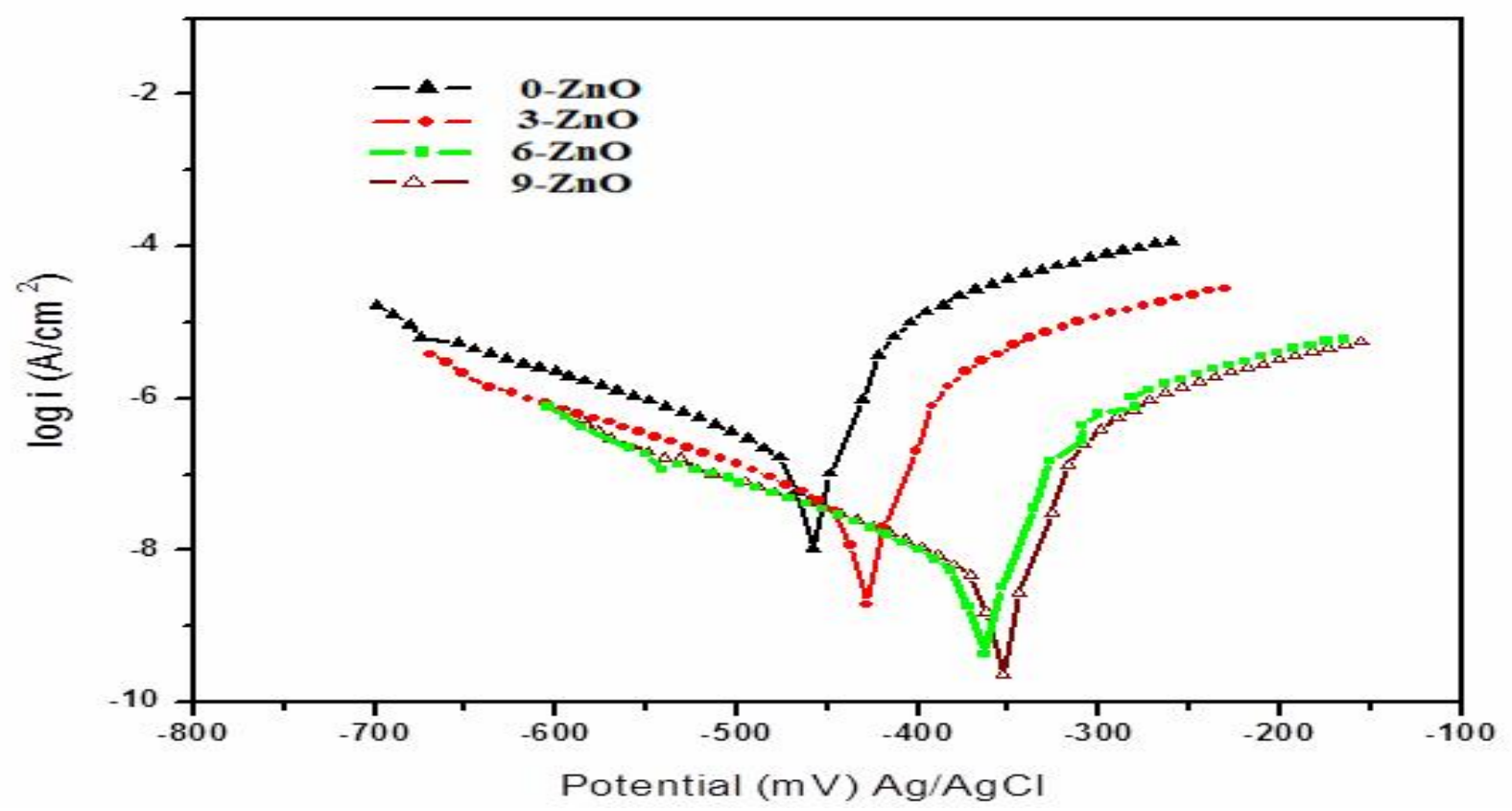

Fig. 10: Potentiodynamic polarization curves of phosphating coating with different Zn concentration alloy in 3.5 wt \% solution 
EFFECT OF ZN CONCENTRATION IONS ON CORROSION BEHAVIOR OF ZINC PHOSPHATE CONVERSION COATING ON AL-MGZN ALLOY

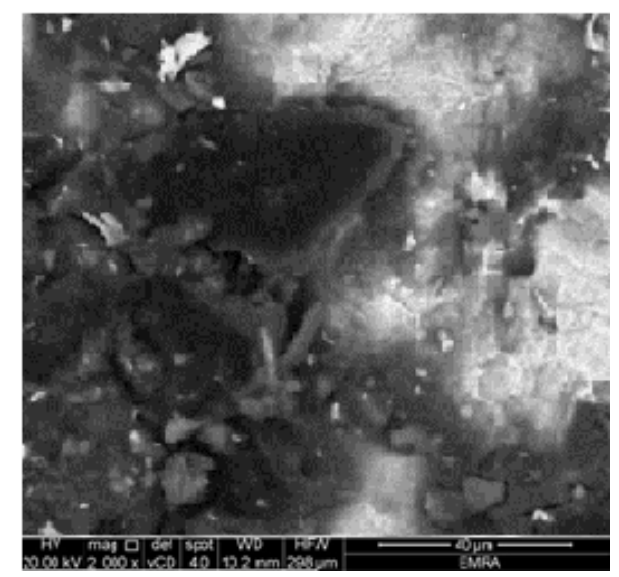

Fig. 11: Morphology of uncoated Al-Mg-Zn alloy after immersion in $3.5 \mathrm{wt} \%$ solution for 15 days
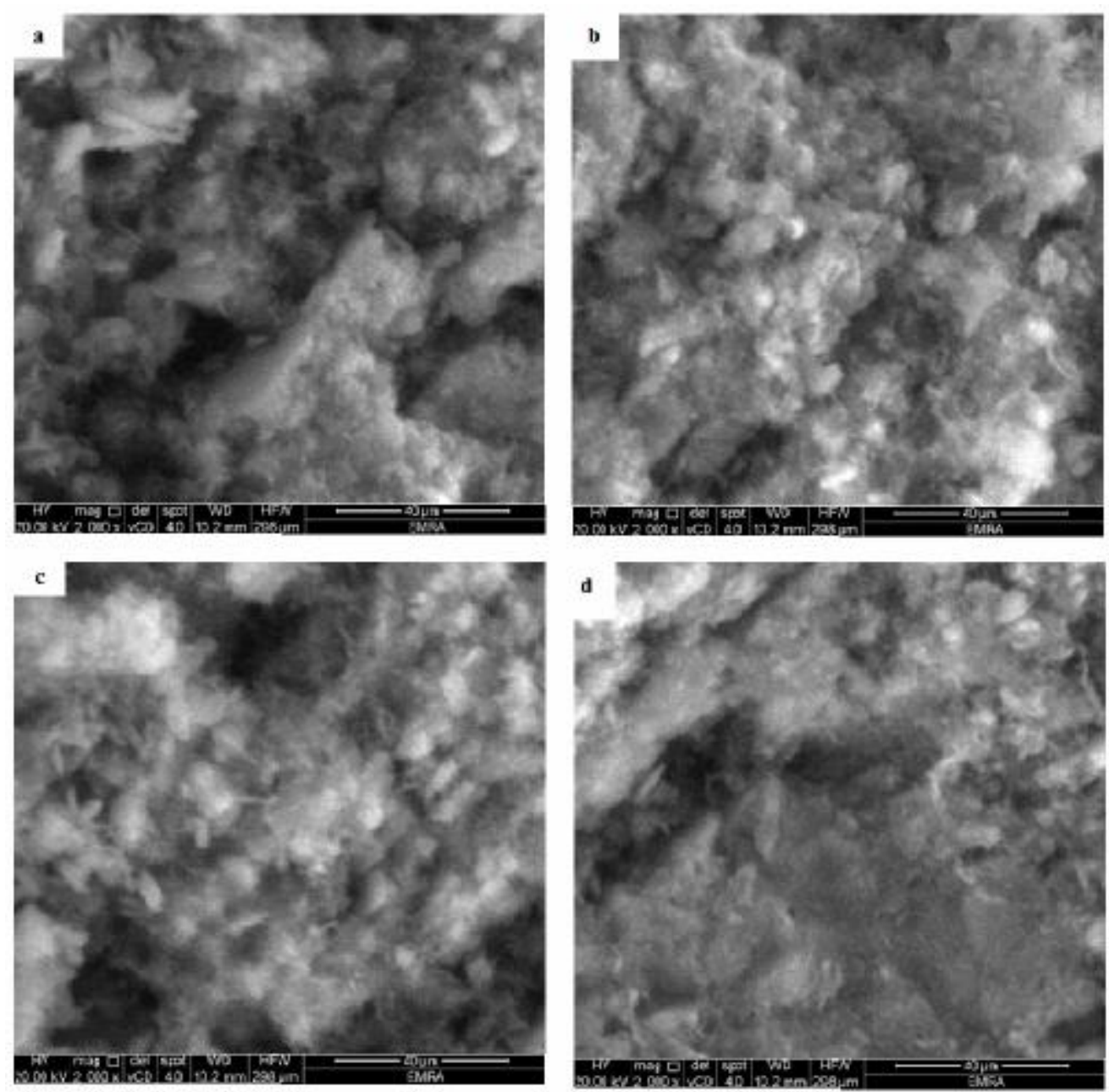

Fig. 12: Morphology of phosphating coating with different $\mathrm{Zn}$ ions concentration after immersion in $3.5 \mathrm{wt} \%$ solution for 15 days. . a-0.0g/L , b-3.0g/L,c-6.0g/L and d- 9.0g/L ZnO 


\section{CONCLUSIONS}

Zinc phosphate conversion coatings were formed on $\mathrm{Al}-\mathrm{Zn}-\mathrm{Mg}$ alloy through immersion in the zinc phosphate conversion solutions. Various concentrations of $\mathrm{Zn}^{2+}$ were applied. The results indicated that the conversion coating consists of hopeite as a single phase. On the other hand, the results indicated that with increasing $\mathrm{Zn}^{2+}$ concentration, the coating formation and growth rates became faster and the zinc phosphate conversion coatings became dense.The corrosion resistance increased with increasing zinc ions concentration and the coating has self-repairing capability in $3.5 \% \mathrm{NaCl}$ solution.

\section{REFERENCES}

1-M. I. ABD EL AAL, M. M. Sadawy, Influence of ECAP as grain refinement technique on microstructure evolution, mechanical properties and corrosion behavior of pure aluminum, Transaction of Nonferrous Metal Society of China (2015) 25, 3865-3876.

2-D. K Heller, W. G. Fahrenholtz, M. J. O'Keefe, The effect of post treatment time and temperature on cerium-based conversion coatings on Al 2024-T3, Corrosion Science 52 (2010) 360-368

3-A. Mahdy, M. M. Sadawy, Effect of Grain Refiner Al-5Ti-1B on the Corrosion and Electrochemical Behavior of Al- 6061 in 3.5wt. \% NaCl Solution, Metall - Internationale Fachzeitschrift für Metallurgie, 2013, Vol. 67, Issue 9, p. 397-401

4-S. Joshi, W.G. Fahrenholtz, M. J. O'Keefe, Effect of alkaline cleaning and activation on aluminum alloy 7075-T6, Applied Surface Science 257 (2011) 1859-1863

5-S.M. Fayed, M. M. Sadawy a, Amir. A. Mahdya, R.Abdel-Karimb, A. Atlam , Evaluation of heat treated Al-Zn$\mathrm{Mg}$ alloy as anode in $\mathrm{KOH}$ electrolyte for aluminium-air batteries, Al -azhar buletin ofscience, 27 (2,) (2016) 112 ,

6-K. Sayuri, V. Benjaminı, S. Margarita, Z. Roumen, B. J. Maria , Anticorrosion behavior of conversion coatings obtained from unbuffered cerium salts solutions on AA6061-T6, journal of rare earths, 29, (10), (2011), 961

7-M.M. Sadawy, M. T. Nooman , Characterization and Corrosion Behaviour of Zinc Phosphate Coatings Reinforcing Steel Bars Formed By Cathodic Treatment, Al-Azhar University Engineering Journal, JAUES , 7(4), Dec. (2012), 1-12.

8-M.M. Sadawy, M.T. Nooman, Formation , R. Elsharkawy, Characterization of Zinc Phosphate coating on Reinforcing Steel Rebars, Journal of Materials Science and Engineering A 3 (7) (2013) 481-487

9-N. Van Phuong, K. H. Lee, D. Chang a, S. Moon, effects of $\mathrm{Zn}^{2+}$ concentration and $\mathrm{pH}$ on the zinc phosphate conversion coatings on AZ31 magnesium alloy, Corrosion Science 60 (2013), 2334-2339

10-R.C. Zeng, F. Zhang, Z.D. Lan, H.Z.i Cui , En. Han, Corrosion resistance of calcium-modified zinc phosphate conversion coatings on magnesium-aluminium alloys, Corrosion Science 88 (2014) 452-459

11- G.Y. Li, J.S. Lian, L.Y. Niu, Z.H. Jiang, Q. Jiang Growth of zinc phosphate coatings on AZ91D magnesium alloy Surface \& Coatings Technology 201 (2006) 1814-1820

12- T.S.N. Sankara Narayanan, Surface pretreatment by phosphate conversion coatings . A REVIEW, 130 T.S.N. Sankara Narayanan Rev.Adv.Mater.Sci. 9 (2005) 130-177

13- J.S. Lian, G.Y. Li, L.Y. Niu, C.D. Gu, Z.H. Jiang, Q. Jiang Electroless Ni-P deposition plus zinc phosphate coating on AZ91D magnesium alloy Surface \& Coatings Technology 200 (2006) 5956-5962

14-S.Jegannathan, T.S.N. Sankara Narayanan, K. Ravichandran a, S. Rajeswari, Performance of zinc phosphate coatings obtained by cathodic electrochemical treatment in accelerated corrosion tests, Electrochimica Acta 51 (2005) 247-256

15- M.M.Sadawy, K.M.Zohdy, Effect of Tin on the Corrosion and Electrochemical Behavior of Al-Zn-Mg Alloy in Sea Water, TMS (The Minerals, Metals \& Materials Society), Light Metals (2014), USA, 383-388 